\title{
OPTIMIZATION OF EXPERIMENTAL FACTORS FOR HEXAVALENT CHROMIUM REMOVAL BY DEAD BIOMASS OF WATER HYACINTH
}

\author{
Sunil Kumar*and Rajesh Dhankhar \\ Department of Environmental Sciences, Maharshi Dayanand University, Rohtak-124001, \\ Haryana, India \\ *E-mail: sunilevs@yahoo.com
}

\begin{abstract}
The purpose of this work was to use the dead biomass of water hyacinth, Eichhornia crassipes (Mart.) solms for hexavalent chromium adsorption from synthetic solution in batch process and surface morphological characterization of adsorbent by FTIR and SEM. Two sizes $(0.3 \mathrm{~mm}$ and $1.0 \mathrm{~mm})$ were prepared from dead biomass. The various experimental factors like $\mathrm{pH}$, contact time, temperature, shaking rate, initial concentration, and dosage of adsorbent on the removal of metal were examined in the batch process. $100 \%$ removal was achieved by both sizes at $1.0 \mathrm{pH}$, when initial concentration, contact time, adsorbent dose, temperature, and shaking speed were 20ppm, 1 hour, $1.0 \mathrm{~g} / 100 \mathrm{ml}, 25^{\circ} \mathrm{c}$, and $150 \mathrm{rpm}$, respectively. It was observed that the percent Cr (VI) removal decline with increasing $\mathrm{pH}$. Similarly, complete removal has been obtained by $0.8 \mathrm{~g}$ and $1.0 \mathrm{~g}$ doses of $0.3 \mathrm{~mm}$ and $1.0 \mathrm{~mm}$ sizes at optimum $\mathrm{pH}$, while other factors are the same as during the $\mathrm{pH}$ study. The study also identified the optimum contact time, initial concentration, temperature, and shaking time. The unloaded and Cr (VI) loaded FT-IR spectra showed a significant shift of absorption peaks. The SEM analysis showed that adsorbent tubes appear to be prominently swollen after $\mathrm{Cr}$ (VI) adsorption as it enters the fibers of the adsorbent. This study concluded that the dead biomass of water hyacinth can be effectively used as an absorbent for wastewater treatment.
\end{abstract}

Keywords: Water Hyacinth, Adsorbent, Chromium (VI), Dead Biomass, Wastewater.

CC RASĀYAN. All rights reserved

\section{INTRODUCTION}

Industrial development activities in recent past such as mining operations, metal plating facilities, tanneries, batteries, fertilizer industries, paper industries, and pesticides, etc., increased by many folds in developing countries, these industries directly or indirectly are accumulating the heavy metals in wastewaters. ${ }^{1}$ Heavy metals ions are not degraded by micro-organism unlike organic pollutants, they start to buildup in living organisms and many of them have the potential to create carcinogenic toxicity. The toxic heavy metals namely mercury, cadmium, lead, zinc, copper, nickel, and chromium are required special attention in wastewaters of industries. ${ }^{2}$

The chromium in the aquatic environment exits as $\mathrm{Cr}$ (III) and $\mathrm{Cr}$ (VI). In general, $\mathrm{Cr}$ (VI) is highly hazardous to the organism in comparison to $\mathrm{Cr}$ (III). ${ }^{3}$ The toxic effects of hexavalent chromium are included, human physiological effects, skin irritation, lung carcinoma, food chain accumulation, and causes several other health problems. ${ }^{4}$ The ion exchange, filtration, chemical precipitation, chemical oxidation and reduction, electrochemical treatment, and bio-reduction are usual methods for removing wastewater heavy metal ions. ${ }^{5,6,7}$ But, these conventional processes of treatment have many drawbacks, including requirements of high energy, insufficient metal elimination, high cost of removal, and production of toxic sludge ${ }^{8}$. Due to these treatment problems, a developing country like India required alternative low-cost technology development for the treatment of $\mathrm{Cr}(\mathrm{VI})$ and other toxic chemicals from industrial effluents. ${ }^{9,10}$ The country like India has poor wastewater treatment facilities and due to the release of untreated effluents most of the water sources have eutrophic, producing an excess of macrophytic plants. These plant wastes have no or very low economic use and inexpensive.

The species Eichhornia crassipes (Mart.) solms (water hyacinth) found in the tropical areas between $40^{\circ} \mathrm{N}$ and $40^{\circ} \mathrm{S}$, it is a member of the pickerelweed family (Pontederiaceae) and abundantly available. This Rasayan J. Chem., 13(4), 2376-2384(2020) http://dx.doi.org/10.31788/ RJC.2020.1345949

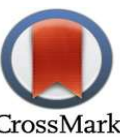


species is a native of central South American countries and Brazil, now shows its presence in streams, wetlands, and swamps of the world including India. ${ }^{11}$ It occupies all the space in the water body very rapidly due to its quick growth with high densities (over $60 \mathrm{~kg} \mathrm{~m}^{-2}$ ). This property of water hyacinth creates bad effects on economic development, aquatic environment, human health and interfere with navigation, recreation, irrigation, and power generation. ${ }^{12}$ Its production on dry basic is 50 tons/hectare/year. ${ }^{13}$ Various researchers are working on the utilization of water hyacinth for useful applications because this is an unwanted/weed for water bodies and responsible for many problems. From the last few decades dried biomass of water- hyacinth has actively researched for the elimination of metals from industrial effluents as a low-cost bioadsorbent. The dead water hyacinth roots have been efficiently used for sorption of uranium, copper as well as basic dyes. ${ }^{14,15} \mathrm{Al}$ Rmalli et al..${ }^{16} \mathrm{demonstrated}$ that powder produced from dried roots of water hyacinth efficiently removes more than $93 \%$ of arsenite As(III) and $95 \%$ of arsenate As (V) from a solution containing $200 \mu \mathrm{g}$ As/ $/ 1$ within $60 \mathrm{~min}$. Keeping in view of water hyacinth waste problem, adsorbent of Eichhornia crassipes collected from Bhindawas wetland, was prepared and the study on removal of Chromium (VI) was conducted. Two different sizes were prepared, upto $0.3 \mathrm{~mm}$ and from $0.3 \mathrm{~mm}$ to $1.0 \mathrm{~mm}$. Surface morphology characterizations were determined with the help of Fourier transform infrared (FTIR) and Scanning electron microscopy (SEM).

\section{Preparation of Adsorbents}

\section{EXPERIMENTAL}

The collection of water hyacinth (Eichhornia sp.) has been done from Bhindawas wetland. The freshwater and distilled water were used to wash the collected water hyacinth plants in the laboratory. The knife was used to cut the plants in the pieces. Initially, plant material was dried under sunlight. Further moisture was removed by drying the plant material in a hot air oven at $110^{\circ} \mathrm{C}$ for $24 \mathrm{hrs}$. The powder of plant material was obtained with the help of a grinder. The color of powder adsorbent was removed by washing with the $1 \%$ formaldehyde solution. The washed adsorbent was dried at a temperature range of $120-140{ }^{\circ} \mathrm{C}$ in an oven for a period of $12 \mathrm{hrs}$. To obtained particle sizes of upto $0.3 \mathrm{~mm}$ and upto $1.0 \mathrm{~mm}$ the dried material was grounded and sieved through a standard sieve.

\section{Characterization of Adsorbent}

The adsorbent characterization was evaluated by using the standard procedure as given in Allen. ${ }^{17}$

\section{$\mathrm{Cr}$ (VI) Solution Preparation and Determination}

The analytical grade Potassium Dichromate $\left(\mathrm{K}_{2} \mathrm{Cr}_{2} \mathrm{O}_{7}\right)$ was taken for $\mathrm{Cr}$ (VI) solution preparation in the batch experiment. The stock solution $(1000 \mathrm{ppm})$ was prepared by mixing $2.829 \mathrm{~g}$ of Potassium Dichromate $\left(\mathrm{K}_{2} \mathrm{Cr}_{2} \mathrm{O}_{7}\right)$ into one liter of double-distilled water. The stock solution was diluted by 50 times to prepare the $20 \mathrm{ppm}$ chromium working solution. 0.25\% 1, 5-Diphenylcarbazide Solution was used to development of violet color in treated samples, and intensity was determined at $540 \mathrm{~nm}$. Chromium (VI) concentration was measured by a standard curve, prepared in the range of 0.2 to $1.4 \mathrm{ppm}$.

\section{Cr (VI) Removal Studies}

The $250 \mathrm{ml}$ conical flasks were used to carry out batch experiments. The $100 \mathrm{ml}$ synthetic solution of chromium was utilized for the optimization of experiments. The batch experiments were carried out by using a mechanical shaker.

The $\mathrm{pH}$, absorbent dose, agitation time, agitation speed,and temperature were optimized with a synthetic solution of chromium in the batch process. The $\mathrm{pH}$ was varying from 1 to 7 to examine the effect of $\mathrm{pH}$, time was kept $1 \mathrm{hr}$, while chromium (VI) concentration, dose, temperature, and agitation speed were $20 \mathrm{ppm}, 1.0 \mathrm{~g} / 100 \mathrm{ml}, 25 \mathrm{C}$, and $150 \mathrm{rpm}$, respectively. The dose was varying from 0.1 to $1.0 \mathrm{gm}$ to assess the effect of adsorbent dose, while other conditions were $20 \mathrm{ppm}$ chromium concentration, 150 rpm agitation speed, temperature $25^{\circ} \mathrm{C}$ and 1 hour agitation time. To assess the effect of agitation time, the study was carried by varying time from 15 to 135 minutes at the interval of 15 minutes while, dose, $\mathrm{pH}$, agitation speed, and temperature were kept $0.3 \mathrm{~g} / 100 \mathrm{ml}, 1,150 \mathrm{rpm}$, and $25 \mathrm{C}$. The influence of concentration, shaking rate, and temperature were evaluated by taking the concentration from 10 to 100 $\mathrm{mg} / \mathrm{l}$, agitation speed from 50 to $300 \mathrm{rpm}$, and 20 to $100{ }^{\circ} \mathrm{C}$ at optimized $\mathrm{pH}$, dose and agitation time.The solution containing conical flasks was removed after a desirable agitation period. The adsorbent was 
settled down after proving two minutes, thereafter Whatman filter paper No. 42 was used to filter solutions. The chromium concentration in the filtrate was measured by spectrophotometer using the diphenylcarbazide method as given in the Standard Method of Water and Waste Water Analysis. ${ }^{18}$

The following equation used to determine the adsorption percentage-

$$
\text { Adsorption }(\%)=\frac{\left(\mathrm{C}_{\mathrm{i}}-\mathrm{C}_{\mathrm{eq}}\right)}{C_{i}} X 100
$$

The initial and the final concentrations of the chromium (VI) are denoted by $\mathrm{C}_{\mathrm{i}}$ and $\mathrm{C}_{\mathrm{eq}}$.

The solid adsorbed chromium (VI) amount was computed as follows:

The per unit weight of the solid adsorbed amount of chromium $(\mathrm{VI})$ at equilibrium $(\mathrm{mg} / \mathrm{g})$

$$
\text { qe }(\mathrm{mg} / \mathrm{g})=\frac{\left(\mathrm{C}_{\mathrm{i}}-\mathrm{C}_{\mathrm{eq}}\right) * \mathrm{~V}}{M}
$$

Where the volume of solution given by V; the mass of adsorbent given by M (gm)

\section{Fourier Transform Infrared (FTIR) Analysis}

The Fourier transform infrared spectrometer (Shimadzu, Japan) was used to produce infrared spectra of the raw and chromium-loaded biosorbent. The translucent sample disks for the FTIR study was prepared by $1 \mathrm{mg}$ of powdered adsorbent encapsulated in $200 \mathrm{mg}$ of $\mathrm{KBr}$ pellet. The functional groups involved in the adsorption of metals were determined by the infrared spectral analysis. The spectral locations of infrared energy adsorption by chemical bonds at specific wavelengths determine the basic structure of compounds. The plot of FTIR was compared with reference spectra for the identification of the material.

\section{SEM Photomicrograph}

The surface physical morphology of the raw and chromium loaded adsorbent was determined by scanning electron microscopy (SEM) technique. The samples were sputter-coated with a thin layer of platinum for charge dissipation. The argon atmosphere was used to operate the sputter coater. The SEM images were got after transferring the sample in the SEM specimen chamber. The raw and chromium-loaded photomicrographs of SEM at various magnifications determine the surface nature of the adsorbent.

\section{RESULTS AND DISCUSSION}

Keeping in view of the abundance of Eichhornia crassipes in Bhindawas wetland adsorption study was done, so that the unwanted Eichhornia crassipes weed can be utilized for some useful purpose. The adsorbent of Eichhornia crassipes was utilized to eliminate the hexavalent chromium from the aqueous solution. Raw Eichhornia crassipes (REC) adsorbent was prepared in two sizes upto $0.3 \mathrm{~mm}$ and $0.3 \mathrm{~mm}$ to $1.0 \mathrm{~mm}$. These adsorbents mark as $0.3 \mathrm{~mm}$ and $1.0 \mathrm{~mm}$ in the study.

\section{Characterization of Adsorbents}

The characterization of adsorbents has been given in Table-1. Raw Eichhornia crassipes (REC) was found slightly basic. The electrical conductivity of REC was $225 \mu \mathrm{mho} / \mathrm{cm}$ for both sizes. Bulk density was found $0.101 \mathrm{~g} / \mathrm{cm}^{3}$ for both sizes. The particle density of REC was noted as $0.145 \mathrm{~g} / \mathrm{cm}^{3}$ and 0.141 $\mathrm{g} / \mathrm{cm}^{3}$ for $0.3 \mathrm{~mm}$ and $1.0 \mathrm{~mm}$ adsorbent sizes, respectively. The adsorbent solubility in water was recorded at $6.4 \%$ and $6.2 \%$ for REC adsorbent of $0.3 \mathrm{~mm}$ and $1.0 \mathrm{~mm}$ sizes, respectively. Similarly, the solubility in acid was $8.3 \%$ and $7.8 \%$ recorded for $0.3 \mathrm{~mm}$ and $1.0 \mathrm{~mm}$. The moisture content of adsorbent REC was recorded $3.25 \%$ for $0.3 \mathrm{~mm}$ size and $2.9 \%$ for $1.0 \mathrm{~mm}$ size. The porosity of REC was $30.3 \%$ for $0.3 \mathrm{~mm}$ size and 28.3 was for $1.0 \mathrm{~mm}$ size.

\section{Adsorption Study of Eichhornia crassipes}

Hexavalent chromium removed by REC was carried out and the influence of various parameters namely $\mathrm{pH}$, adsorption dose, agitation time, initial $\mathrm{Cr}(\mathrm{VI})$ concentration, rotation per minute (rpm) of the shaker, and temperature in batch on Cr (VI) removal was studied. All experiments were carried out in the batch process.

\section{Effect of pH}

The influence of $\mathrm{pH}$ on $\mathrm{Cr}$ (VI) reduction by REC is shown in Table-2. The $\mathrm{pH}$ effect on Cr (VI) removal was evaluated by using $20 \mathrm{ppm}$ initial $\mathrm{Cr}$ (VI) concentration with $1 \mathrm{~g} / 100 \mathrm{ml}$ of adsorbent dose for $0.3 \mathrm{~mm}$ 
RASĀYAN J. Chem.

Vol. 13 | No. 4 |2376-2384| October - December | 2020

and $1.0 \mathrm{~mm}$ sizes, where $\mathrm{pH}$ was varied from 1 to 7 . The $0.1 \mathrm{~N} \mathrm{HCl}$ and $0.1 \mathrm{~N} \mathrm{NaOH}$ solutions were used to adjust the $\mathrm{pH}$.

Table-1: Characterization of Adsorbents prepared from Eichhornia crassipes

\begin{tabular}{|c|c|c|}
\hline \multirow[t]{2}{*}{ Parameters } & \multicolumn{2}{|c|}{ Raw Eichhornia crassipes(REC) } \\
\hline & $0.3 \mathrm{~mm}$ & $1.0 \mathrm{~mm}$ \\
\hline $\mathrm{pH}$ & 6.75 & 6.75 \\
\hline $\mathrm{EC} \mu \mathrm{mho} / \mathrm{cm}$ & 225 & 225 \\
\hline Bulk density $\mathrm{g} / \mathrm{cm}^{3}$ & 0.101 & 0.101 \\
\hline Particle density $\mathrm{g} / \mathrm{cm}^{3}$ & 0.145 & 0.141 \\
\hline Solubility in Water (\%) & 6.4 & 6.2 \\
\hline Solubility in Acid (\%) & 8.3 & 7.8 \\
\hline Moisture Content $(\%)$ & 3.25 & 2.9 \\
\hline Porosity $(\%)$ & 30.3 & 28.3 \\
\hline
\end{tabular}

The percent of $\mathrm{Cr}(\mathrm{VI})$ removal by $0.3 \mathrm{~mm}$ and $1.0 \mathrm{~mm}$ sizes were $100 \%$ at $\mathrm{pH} 1.0$. The results revealed that $\mathrm{Cr}(\mathrm{VI})$ removal decline with increasing $\mathrm{pH}$. The removal percentages of $\mathrm{Cr}(\mathrm{VI})$ at $2 \mathrm{pH}$ for $0.3 \mathrm{~mm}$ and $1.0 \mathrm{~mm}$ were $71 \%$ and $69.3 \%$, respectively. The removals by adsorbents per unit mass were $1.42 \mathrm{mg} / \mathrm{g}$ and $1.386 \mathrm{mg} / \mathrm{g}$ at $2 \mathrm{pH}$, respectively. The ionic state of functional groups along with the metal chemistry in solution is the deciding factor for the influence of the $\mathrm{pH}$ on metal removal. ${ }^{19}$

\begin{tabular}{c|c|c|c|c}
\multicolumn{2}{c}{ Table-2: Effect of $\mathrm{pH}$ on Cr (VI) Removal by Raw Eichhornia crassipes (REC) } \\
\hline \multirow{2}{*}{$\mathrm{pH}$} & \multicolumn{2}{|c|}{ REC $(0.3 \mathrm{~mm})$} & \multicolumn{2}{c}{ REC $(1.0 \mathrm{~mm})$} \\
\cline { 2 - 5 } & $\%$ Removal & Removal in $\mathrm{mg} / \mathrm{g}$ & \% Removal & Removal in $\mathrm{mg} / \mathrm{g}$ \\
\hline 1 & 100 & 2.0 & 100 & 2.0 \\
\hline 2 & 71 & 1.42 & 69.3 & 1.386 \\
\hline 3 & 52.7 & 1.054 & 49.5 & 0.989 \\
\hline 4 & 51.1 & 1.022 & 48.5 & 0.969 \\
\hline 5 & 49.8 & 0.996 & 47.1 & 0.943 \\
\hline 6 & 48.8 & 0.977 & 45.8 & 0.916 \\
\hline 7 & 46.2 & 0.924 & 44.1 & 0.883 \\
\hline
\end{tabular}

Initial Cr (VI) - 20 ppm, Dose $-1.0 \mathrm{~g} / 100 \mathrm{ml}$, Time - 1hour, Temperature $-25^{\circ} \mathrm{C}, \mathrm{RPM}-150$

The functional groups with positive charge present on the bioadsorbent surface bind to negatively charged chromium species (chromate/dichromate) at $\mathrm{pH} 1.0$ because the positive charge is carried by many functional groups at this $\mathrm{pH}$. The main species that present at acidic $\mathrm{pH}$ were $\mathrm{Cr}_{2} \mathrm{O}_{7}^{2-}, \mathrm{HCrO}_{4}^{-}, \mathrm{Cr}_{3} \mathrm{O}_{10^{2-}}$ and $\mathrm{Cr}_{4} \mathrm{O}_{13}{ }^{2-}$ in solution, ${ }^{20}$ while above $\mathrm{pH} 7$, only $\mathrm{CrO}_{4}{ }^{2-}$ was dominated. Moreover at lower $\mathrm{pH} \mathrm{Cr}_{3} \mathrm{O}_{10}{ }^{2-}$ and $\mathrm{Cr}_{4} \mathrm{O}_{13}{ }^{2-}$ species are formed. Thus at lower $\mathrm{pH}$ more polymerized $\mathrm{Cr}$ oxide species are formed. Similarly, the uptake of $\mathrm{Cr}$ (VI) under acidic conditions by adsorbent becomes highly protonated and favorable. ${ }^{21}$ Furthermore, competition between $\mathrm{OH}^{-}$and chromate ions $\left(\mathrm{CrO}_{4}{ }^{2-}\right)$ at basic $\mathrm{pH}$ reduces the adsorption because $\mathrm{OH}^{-}$was the main species at higher $\mathrm{pH}$.

\section{Effect of Adsorbent Dose}

The Cr (VI) removal at various dosages from 0.1 to $1.0 \mathrm{~g}$ of REC $(0.3 \mathrm{~mm} \& 1.0 \mathrm{~mm})$ has been given in Table-3. The experiment was performed at $20 \mathrm{ppm}$ initial $\mathrm{Cr}$ (VI) concentration, 1 hour agitation time, $\mathrm{pH}$ 1.0 , temperature $25^{\circ} \mathrm{C}$, and $150 \mathrm{rpm}$ agitation rate.

It was found from the outcome that removal of $\mathrm{Cr}(\mathrm{VI})$ by $0.3 \mathrm{~mm}$ and $1.0 \mathrm{~mm}$ adsorbents were increased from $72.2 \%$ to $100 \%$ at $0.1 \mathrm{~g}$ to $0.8 \mathrm{gm}$ dosages and $71.5 \%$ to $100 \%$ at $0.1 \mathrm{~g}$ to $1.0 \mathrm{~g}$ for REC.The $80.7 \%$ and $78.5 \%$ removal of $\mathrm{Cr}(\mathrm{VI})$ for $0.3 \mathrm{~mm}$ and $1.0 \mathrm{~mm}$ took place at $0.3 \mathrm{~g}$, where per unit mass removal was $5.38 \mathrm{mg} / \mathrm{g}$ and $5.23 \mathrm{mg} / \mathrm{g}$, which is a significant amount of removal. So for further study $0.3 \mathrm{~g}$ of REC/ $100 \mathrm{ml}$ dosage was taken for both sizes. The number of particles per unit weight increased when increased in adsorption dose, which provides more binding sites with more surface area for adsorption. Typical saturation in terms of \%age removal has been observed after certain adsorbent doses. It could be due to an increased competition level between the adsorbent particles for the binding of metal substances. ${ }^{22}$ The study revealed that a slightly higher removal rate was observed in $0.3 \mathrm{~mm}$ than $1.0 \mathrm{~mm}$ size. The surface area of the adsorbent decreases with increasing particle size. Furthermore, the migration 
RASĀYAN J. Chem.

Vol. 13 | No. 4 |2376-2384| October - December | 2020

time of the metal ions into inner pores increased with increasing particle size, which results in longer equilibrium time with lower sorption capacity. ${ }^{16}$

Table-3: Effect of Dose on Cr (VI) Removal by Raw Eichhornia crassipes(REC)

\begin{tabular}{c|c|c|c|c}
\hline \multirow{2}{*}{$\begin{array}{c}\text { Dose } \\
(\mathrm{g} / 100 \mathrm{ml})\end{array}$} & \multicolumn{2}{|c|}{ REC $(0.3 \mathrm{~mm})$} & \multicolumn{2}{c}{ REC $(1.0 \mathrm{~mm})$} \\
\cline { 2 - 5 } & \% Removal & Removal in $\mathrm{mg} / \mathrm{g}$ & \% Removal & Removal in $\mathrm{mg} / \mathrm{g}$ \\
\hline 0.1 & 72.2 & 14.43 & 71.5 & 14.3 \\
\hline 0.2 & 75.9 & 7.59 & 75.1 & 7.5 \\
\hline 0.3 & 80.7 & 5.38 & 78.5 & 5.23 \\
\hline 0.4 & 97.4 & 4.86 & 94 & 4.7 \\
\hline 0.5 & 97.7 & 3.9 & 96.6 & 3.86 \\
\hline 0.6 & 98.1 & 3.27 & 97.3 & 3.24 \\
\hline 0.7 & 99.5 & 2.84 & 98.9 & 2.82 \\
\hline 0.8 & 100 & 2.5 & 99.2 & 2.48 \\
\hline 0.9 & -- & -- & 99.6 & 2.21 \\
\hline 1.0 & -- & -- & 100 & 2.0 \\
\hline
\end{tabular}

Initial $\mathrm{Cr}(\mathrm{VI})-20 \mathrm{ppm}, \mathrm{pH}-1$, Time -1 hour, Temperature $-25^{\circ} \mathrm{C}, \mathrm{RPM}-150$

\section{Effect of Adsorbent Time}

The variation of $\mathrm{Cr}(\mathrm{VI})$ reduction from synthetic solution by REC absorbent sizes of $0.3 \mathrm{~mm}$ and $1.0 \mathrm{~mm}$ concerning agitation time exhibits in Table-4. The experiment was performed at $20 \mathrm{ppm}$ initial $\mathrm{Cr}$ (VI) concentration, a dose of absorbent was $0.3 \mathrm{~g} / 100 \mathrm{ml}, \mathrm{pH}$ was 1 , the temperature was $25^{\circ} \mathrm{C}$, agitation at 150 rpm, while contact time was varied from 15 minutes to 135 minutes.

It has been highlighted from the outcome that $\mathrm{Cr}$ (VI) reduction by REC sizes of $0.3 \mathrm{~mm}$ and $1.0 \mathrm{~mm}$ increased from $64.5 \%$ to $93.6 \%$ and $63.7 \%$ to $92.7 \%$, respectively at 15 minutes to 120 minutes of contact time. The removal per unit mass was increased from $4.29 \mathrm{mg} / \mathrm{g}$ to $6.23 \mathrm{mg} / \mathrm{g}$ for $0.3 \mathrm{~mm}$ and $4.24 \mathrm{mg} / \mathrm{g}$ to $6.18 \mathrm{mg} / \mathrm{g}$ for $1.0 \mathrm{~mm}$. It was also noted that a significant amount of $\mathrm{Cr}$ (VI) removal took place at 60 minutes, so further experiments were conducted by taking 60 minutes as an agitation time.

The outcome of the study showed that initially,the reduction rate was high, but after the lapse of time, it was slower. Higher removal in the starting time could be due to more adsorption sites availability, higher metal concentration gradient, electrostatic affinity and ion-exchange at an earlier stage. It was also noted that the removal of metal ions increase with the increasing agitation time to some extent. Further agitation time increase did not increase the uptake of metal ion on the adsorbent.

\begin{tabular}{c|c|c|c|c}
\multicolumn{2}{c}{ Table-4: Effect of Time on Cr (VI) Removal by Raw Eichhornia crassipes (REC) } \\
\hline \multirow{2}{*}{$\begin{array}{c}\text { Time } \\
(\text { Min })\end{array}$} & \multicolumn{2}{|c}{ REC $(0.3 \mathrm{~mm})$} & \multicolumn{2}{c}{ REC $(1.0 \mathrm{~mm})$} \\
\cline { 2 - 5 } & \% Removal & Removal in mg/g & \% Removal & Removal in $\mathrm{mg} / \mathrm{g}$ \\
\hline 15 & 64.5 & 4.29 & 63.7 & 4.24 \\
\hline 30 & 69.6 & 4.64 & 67.8 & 4.52 \\
\hline 45 & 76 & 5.06 & 74.6 & 4.97 \\
\hline 60 & 80.7 & 5.38 & 78.5 & 5.23 \\
\hline 75 & 84 & 5.59 & 82.3 & 5.48 \\
\hline 90 & 90.8 & 6.05 & 90 & 5.99 \\
\hline 105 & 91.8 & 6.12 & 91.3 & 6.08 \\
\hline 120 & 93.6 & 6.23 & 92.5 & 6.16 \\
\hline 135 & 93.6 & 6.23 & 92.7 & 6.18 \\
\hline
\end{tabular}

Initial $\mathrm{Cr}(\mathrm{VI})-20 \mathrm{ppm}, \mathrm{pH}-1$, Dose $-0.3 \mathrm{~g} / 100 \mathrm{ml}$, Temperature $-25{ }^{\circ} \mathrm{C}, \mathrm{RPM}-150$

A similar outcome has been reported by several other authors for the adsorption of metals on Eichhornia crassipes adsorbent. ${ }^{16,19,23}$ Equilibrium time depends upon the initial metal concentration and affinity of metal binding.The equilibrium time reported by Mohanty et al. ${ }^{19}$ for $10 \mathrm{mg} / 1$ initial concentration of $\mathrm{Cr}$ (VI) was $360 \mathrm{~min}$ on Eichhornia crassipes adsorbent. Where in the current investigation equilibrium time was $135 \mathrm{~min}$ for $20 \mathrm{mg} / \mathrm{l} \mathrm{Cr}$ (VI) concentration. The equilibrium time required by the adsorbent of Eichhornia crassipes used in the currentwork is lower in comparison to others reported equilibrium time in literature. The equilibrium time is considered an important aspect of economical water and wastewater 
RASĀYAN J. Chem.

Vol. 13 | No. 4 |2376-2384| October - December | 2020

treatment applications. The rapid (or instantaneous) biosorption phenomenon is advantageous in-process application because smaller size treatment equipment is required in case of shorter contact time adsorbent.

\section{Effect of Initial Cr (VI) Concentration}

The experiment was conducted at various $\mathrm{Cr}$ (VI) concentrations i.e. 10-100 ppm. The dosage of adsorbent was kept $0.3 \mathrm{~g} / 100 \mathrm{ml}, \mathrm{pH}$ was 1.0 , temperature $25^{\circ} \mathrm{C}$, rpm was 150 at the contact time of 1hour. The removal results have been presented in Table-5.

The elimination of $\mathrm{Cr}(\mathrm{VI})$ concentration was found a maximum of $100 \%$ and $99.1 \%$ at $10 \mathrm{ppm}$ initial $\mathrm{Cr}$ (VI) concentration by $0.3 \mathrm{~mm}$ and $1.0 \mathrm{~mm}$ REC adsorbent. Removal by per unit mass was maximum 15.26 $\mathrm{mg} / \mathrm{g}$ for $0.3 \mathrm{~mm}$ and $14.09 \mathrm{mg} / \mathrm{g}$ for $1.0 \mathrm{~mm}$ at $100 \mathrm{ppm}$. It could be due to the more metal ions was available to adsorbed per unit mass at higher concentration adsorbate.A greater concentration gradient was formed during higher metal concentration and the quicker the $\mathrm{Cr}(\mathrm{VI})$ ions transferred on the surface of REC from a liquid solution. The percentage of removal was decreased with increasing $\mathrm{Cr}$ (VI) concentration. The minimum percent reduction of $\mathrm{Cr}(\mathrm{VI})$ was recorded 45.7 for $0.3 \mathrm{~mm}$ and $42.3 \%$ for $1.0 \mathrm{~mm}$ size at $100 \mathrm{ppm}$. The limited numbers of active sites were occupied and saturated quickly at a higher metal concentration in comparison to lower concentrations. The outcome suggested that $\mathrm{Cr}$ (VI) elimination by REC was extremely concentration-dependent.

Table-5: Effect of Initial Concentration on Cr (VI) Removal by Raw Eichhornia crassipes (REC)

\begin{tabular}{c|c|c|c|c}
\hline \multirow{2}{*}{$\begin{array}{c}\text { Initial Conc. } \\
(\mathrm{ppm})\end{array}$} & \multicolumn{2}{|c|}{ REC $(0.3 \mathrm{~mm})$} & \multicolumn{2}{c}{ REC (1.0mm) } \\
\cline { 2 - 5 } & \% Removal & Removal in $\mathrm{mg} / \mathrm{g}$ & \% Removal & Removalin $\mathrm{mg} / \mathrm{g}$ \\
\hline 10 & 100 & 3.33 & 99.1 & 3.30 \\
\hline 20 & 80.7 & 5.38 & 78.5 & 5.23 \\
\hline 30 & 87 & 8.7 & 82.2 & 8.22 \\
\hline 40 & 89.2 & 11.89 & 84.9 & 11.31 \\
\hline 50 & 69.7 & 11.61 & 68.3 & 11.38 \\
\hline 60 & 50.5 & 10.09 & 48.3 & 12.99 \\
\hline 70 & 42.8 & 9.99 & 41.5 & 9.68 \\
\hline 80 & 41.7 & 11.12 & 38.6 & 10.30 \\
\hline 90 & 45.8 & 13.74 & 40.1 & 12.04 \\
\hline 100 & 45.7 & 15.26 & 42.3 & 14.09 \\
\hline
\end{tabular}

Time - 1hour, $\mathrm{pH}-1$, Dose $-0.3 \mathrm{~g} / 100 \mathrm{ml}$, Temperature $-25^{\circ} \mathrm{C}, \mathrm{RPM}-150$

\section{Effect of Shaking Rate}

The experiment was conducted at various shaking rates i.e. 50-300 rpm. The dosage was taken as 0.3 $\mathrm{g} / 100 \mathrm{ml}, \mathrm{pH}$ was 1.0 , and the temperature was $25^{\circ} \mathrm{C}$, at the contact time of 1 hour. The outcomes have been presented in Table-6.

The reduction of $\mathrm{Cr}$ (VI) amount was increased from 72.9 to $97.8 \%$ for $0.3 \mathrm{~mm}$ and $72 \%$ to $97.3 \%$ for $1.0 \mathrm{~mm}$ size when the agitation rate increased from $50 \mathrm{rpm}$ to $300 \mathrm{rpm}$. This could be due to the diffusion coefficient of the metal ion in the solution was increased, which led to increased mass transfer flux with increasing shaking rate.

\section{Effect of Temperature}

The effect of temperature on the removal of $\mathrm{Cr}$ (VI) by REC was assessed by experimenting with temperatures range of 20 to $100{ }^{\circ} \mathrm{C}$ (interval $20{ }^{\circ} \mathrm{C}$ ), $\mathrm{pH} 1.0, \mathrm{Cr}(\mathrm{VI})$ concentrations of 20ppm, adsorbent dosage $0.3 \mathrm{~g} / 100 \mathrm{ml}$ and contact time 1 hour. Maximum removal was $94 \%$ for $0.3 \mathrm{~mm}$ and $90.2 \%$ for 1.0 $\mathrm{mm}$ adsorbent size at $100^{\circ} \mathrm{C}$. The removal efficiency minimum at $40^{\circ} \mathrm{C}$ temperature (Table-7). This might be contributed by the deteriorating of hydrogen bonds and intermolecular bonding at this temperature, resulting in the poorer activation of sites and physical interaction between REC adsorbent and $\mathrm{Cr}$ (VI). ${ }^{24} \mathrm{It}$ was noted that adsorption and uptake of $\mathrm{Cr}(\mathrm{VI})$ increased with increasing temperature from 60 to $100^{\circ} \mathrm{C}$. The inclined in adsorption with increasing temperature suggests the adsorption process was endothermic. A similar investigation using the different adsorbent system also reported the endothermic nature of the adsorption process. ${ }^{25}$ The higher temperature decline the thickness of the boundary layer of adsorbent 
RASĀYAN J. Chem.

Vol. 13 | No. 4 |2376-2384| October - December | 2020

with decreasing the mass transfer resistance, resulting in more number of active surface sites available for adsorption. ${ }^{26}$

\section{Infrared Spectroscopic Studies(FTIR)}

The untreated sample of REC and Cr (VI) loaded sample was analyzed by Fourier transform infrared spectroscopy (FTIR) and the transmissions percentage for different wave numbers is depicted in Fig.-1. The spectra of REC sample confirmed the occurrence of several functional groups on the adsorbent surface, the adsorption of chromium ions facilitated by these functional groups. The bonded hydroxyl group and NH stretch are shown by a broad absorption peak around $3388 \mathrm{~cm}^{-1}$. The peak noted at 1640 $\mathrm{cm}^{-1}$ can be indicative of $\mathrm{C}=\mathrm{O}$ stretch and $1429 \mathrm{~cm}^{-1}$ (mainly $\mathrm{NO}_{2}$ antisym stretch) can be recognized to the $\mathrm{NO}_{2}$ in aromatic nitro compounds. It was clear that the $\mathrm{CH}_{2} \mathrm{OH}$ in primary alcohols gave rise to one band: C-O stretch at $1056 \mathrm{~cm}^{-1}$, where $1247 \mathrm{~cm}^{-1}$ gave rise AR-O in alkyl ethers to another band of C-O. The $\mathrm{COO}$ group in carboxylic acid with Antisym stretch was observed at $1375 \mathrm{~cm}^{-1}$. The $\mathrm{CH}_{2}$ stretching was also noted by the spectrum band at about $896 \mathrm{~cm}^{-1}$. The native and chromium-loaded biomass showed the significant shifting of absorption peaks in FT-IR spectra. The carboxylic acids and other compounds having "benzyl" hydrogen to benzoic acids and primary and secondary alcohols related to ketones were oxidized by $\mathrm{Cr}(\mathrm{VI})$ and it reduces to trivalent form. ${ }^{27}$

\section{SEM Analysis}

This study also investigates the morphology of Raw Eichhornia crassipes (REC) and Cr (VI) loaded adsorbent using the scanning electron microscope. The SEM pictures of the REC and Cr (VI) loaded REC are shown in Fig.-2. The raw powdered REC shows the tubular structures and irregular symmetry in the SEM image. The Cr (VI) loaded SEM image shows the swollen tubes due to the entering of chromium in fibers of the REC adsorbent. The SEM results indicated that functional groups available inside the REC adsorbent wall adsorbed the $\mathrm{Cr}(\mathrm{VI})$.

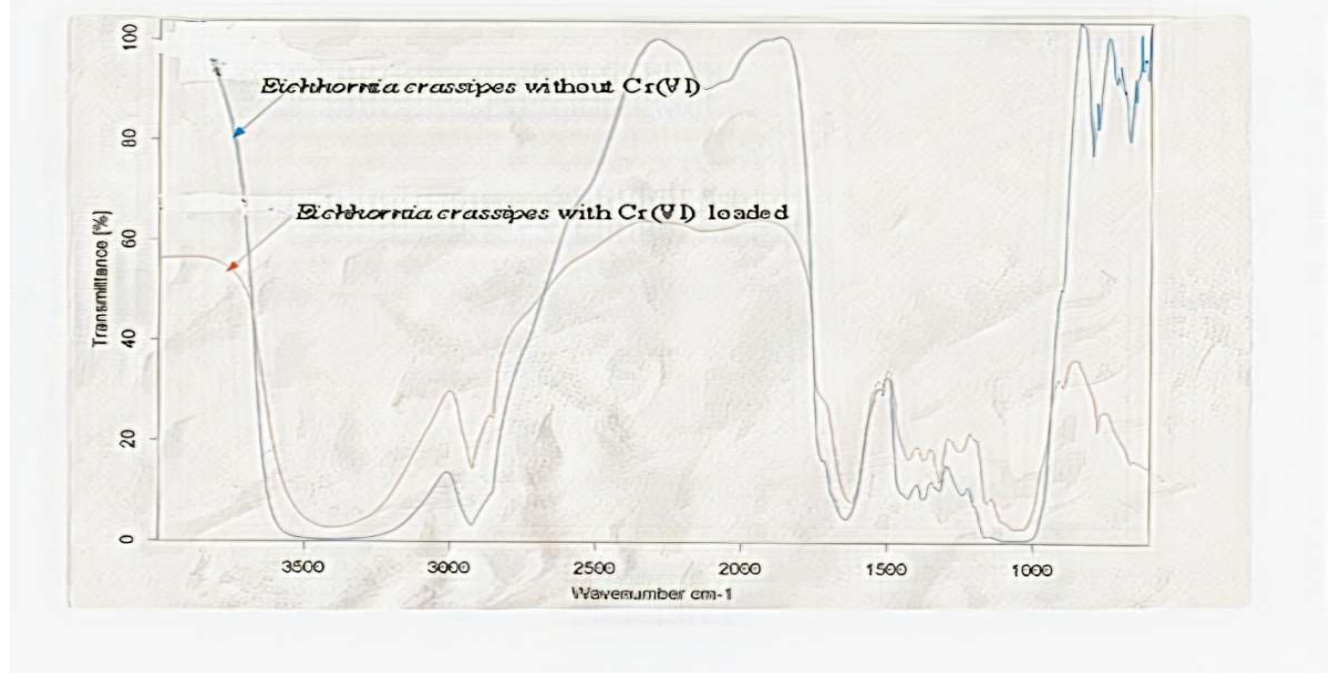

Fig.-1: Comparison of FTIR Spectrum of Raw Eichhornia crassipes (REC) Adsorbent without and with Cr (VI) loaded

Table-6: Effect of Shaking Rate (rpm) on Cr (VI) Removal by Raw Eichhornia crassipes

\begin{tabular}{c|c|c|c|c}
\hline \multirow{2}{*}{ RPM } & \multicolumn{2}{|c|}{ REC $(0.3 \mathrm{~mm})$} & \multicolumn{2}{c}{ REC (1.0mm) } \\
\cline { 2 - 5 } & \% Removal & Removal in mg/g & \% Removal & Removal in m/g \\
\hline 50 & 72.9 & 4.86 & 72 & 4.8 \\
\hline 100 & 83.8 & 5.58 & 77.5 & 5.16 \\
\hline 150 & 85.4 & 5.69 & 78.5 & 5.23 \\
\hline 200 & 93.8 & 6.25 & 91.4 & 6.09 \\
\hline 250 & 95.8 & 6.38 & 95.1 & 6.34 \\
\hline 300 & 97.8 & 6.52 & 97.3 & 6.49 \\
\hline \multicolumn{4}{|c|}{2382}
\end{tabular}


RASĀYAN J. Chem.

Vol. 13 | No. 4 |2376-2384| October - December | 2020

Time - 1hour, $\mathrm{pH}-1$, Dose $-0.3 \mathrm{~g} / 100 \mathrm{ml}$, Temperature $-25^{\circ} \mathrm{C}$, Initial $\mathrm{Cr}(\mathrm{VI})-20 \mathrm{ppm}$

Table-7: Effect of Temperature on Cr (VI) Removal by Raw Eichhornia crassipes (REC)

\begin{tabular}{c|c|c|c|c}
\hline \multirow{2}{*}{ Temp. } & \multicolumn{2}{|c|}{ REC $(0.3 \mathrm{~mm})$} & \multicolumn{2}{c}{ REC (1.0mm) } \\
\cline { 2 - 5 } & \% Removal & $\mathrm{mg} / \mathrm{g}$ Removal & \% Removal & $\mathrm{mg} / \mathrm{g}$ Removal \\
\hline 20 & 80.7 & 5.38 & 78.5 & 5.24 \\
\hline 40 & 72.5 & 4.83 & 64.6 & 4.31 \\
\hline 60 & 79.6 & 5.31 & 72.9 & 4.86 \\
\hline 80 & 86.7 & 5.77 & 85.9 & 5.73 \\
\hline 100 & 94 & 6.26 & 90.2 & 6.01 \\
\hline
\end{tabular}

Time - 1hour, $\mathrm{pH}-1$, Dose $-0.3 \mathrm{~g} / 100 \mathrm{ml}$, Initial Cr (VI) - 20 ppm
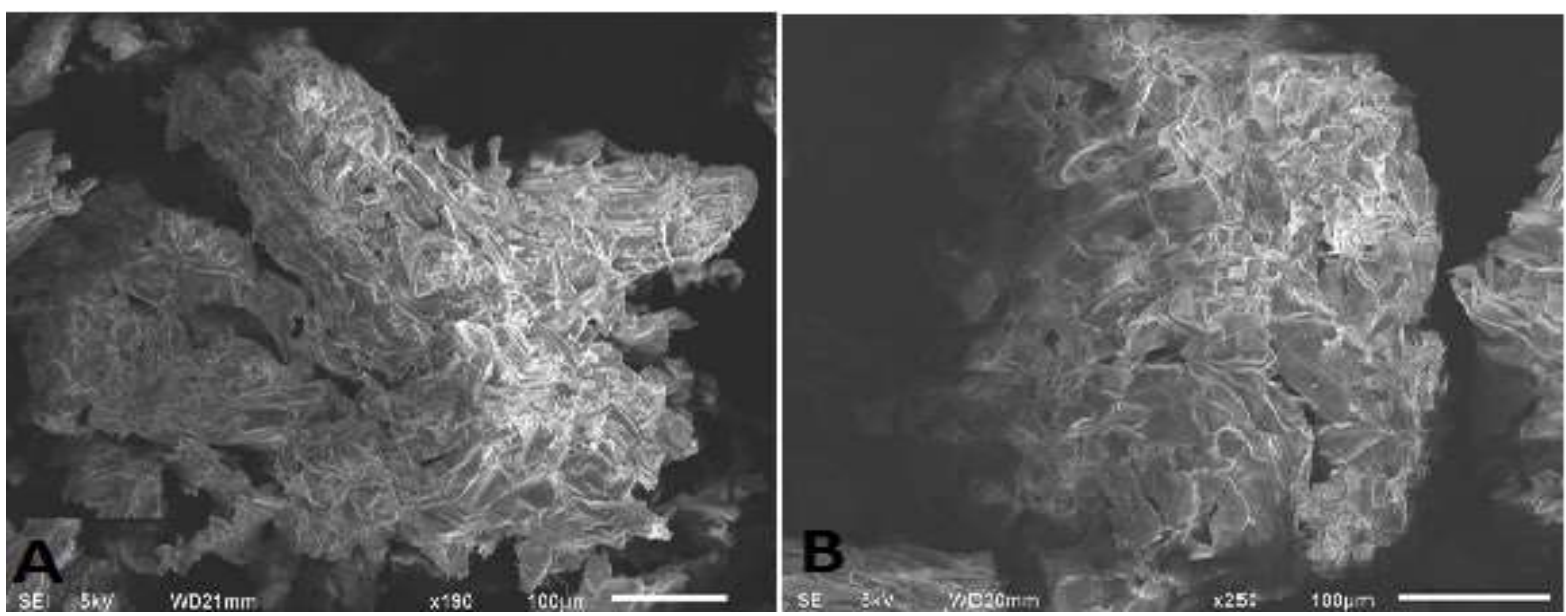

Fig.-2: SEM Image of Raw Eicchornia crassipes before (A) and after (B) Cr (VI) loaded

\section{CONCLUSION}

The main problem associated with eutrophic water is weed infestation, $70 \%$ of the waterlogged area of many wetlands is covered with the Eichhornia crassipes. For many decades, researchers are involved to find out the useful application of Eichhornia crassipes. The current study was also an attempt to utilize this unwanted aquatic weed for the treatment of wastewater by preparing adsorbent from dead biomass.Two different particle sizes were prepared, upto $0.3 \mathrm{~mm}$ and upto $1.0 \mathrm{~mm}$. A decrease in adsorbent size slightly improves the removal efficiency, which indicates the surface area increases with the reduction of particle size. $100 \%$ removal was achieved at $\mathrm{pH} 1$ by using $1 \mathrm{gm} / 100 \mathrm{ml}$ of adsorbent dose at 1 hour shaking time. The removal of metals improved with increasing contact time till the equilibrium was reached. The chromium (VI) reduction was declined with increasing adsorbate concentration, while the amount of adsorbate uptake (q) per unit weight of the adsorbent was increased. The removal of chromium (VI) initially decreased with increased temperature, but after $60^{\circ} \mathrm{C}$ gradually increased in the removal percentage. Chromium (VI) removal increasing with increased shaking speed.The present investigation shows that weed-like Eichhornia crassipes can be used in the treatment of wastewaters as an effective adsorbent.

\section{ACKNOWLEDGEMENT}

The authors are thankful for the department of Genetic and the department of Chemistry, M.D.U Rohtak to provide facilities for FTIR and SEM studies.

\section{REFERENCES}

1. E. A. Ofudje1, I. A. Adeogun, M. A. Idowu, S. O. Kareem and N. A. Ndukwe, Journal of Analytical Science and Technology,11, 7(2020), DOI:10.1186/s40543-020-0206-0

2. Ş. Parlayici and E. Pehlivan, Journal of Analytical Science and Technology,10, 15(2019), DOI: 10.1186/s40543-019-0175-3

3. J. Bayuo1, K. B. Pelig-Ba1 and M. A. Abukar, Applied Water Science ,9, 107(2019), DOI: $10.1007 / \mathrm{s} 13201-019-0987-8$ 
RASĀYAN J. Chem.

Vol. 13 | No. 4 |2376-2384| October - December | 2020

4. L. Khezami and R. Capart, Journal of Hazardous Materials, 123, 223(2005), DOI:10.1016/j.jhazmat. 2005.04.012

5. A. Singh, S. Kumar, V. Panghal, S. S. Arya and S. Kumar, Rasayan Journal of Chemistry, 12 (4), 1956 (2019), DOI: 10.31788/RJC.2019.1245401

6. S.Sultan and S. Hasnain, Bioresource Technology, 98, 340(2007), DOI:10.1016/j.biortech. 2005.12.025

7. B. Mukhopadhyay, J. Sundquist and R.J Schmitz, Journal of Environment Management ,82, 66(2007), DOI:10.1016/j.jenvman.2005.12.005

8. B. Volesky and Z.R. Holan, Biotechnology Progress, 11,235(1995), DOI:10.1021/bp00033a001

9. V. Panchal, A. Ghosh, P. C. Tomar and S. S. Chapadgaonkar, Rasayan Journal of Chemistry, 13 (2), 949(2020), DOI: 10.31788/RJC.2020.1325404

10. R. E. K. Billah, Y. Elyamani, Y. Rakhila, M. Agunaou and A. Soufiane, Rasayan Journal of Chemistry, 12(1), 347(2019), DOI:10.31788/RJC.2019.1215078

11. T.D. Center, 1994, Biological control of weeds: water hyacinth and water lettuce, in: D. Rosen, F.D. Bennett and J.L. Capinera (Eds), Pest management in the subtropics, biological control—a Florida perspective, UK: Intercept Ltd, pp. 481.

12. P. Epstein, Lancet, 351, 577(1998), DOI:10.1016/s0140-6736(05)78570-6

13. A. Malik, Environment International, 33, 122(2007), DOI:10.1016/j.envint.2006.08.004

14. K.S. Low, C.K. Lee and C.H Tai, Journal of Environmental Science and Health A, 29, 171(1994), DOI: $10.1080 / 10934529409376028$

15. S. Shawky, M. A. Geleel and A. Aly, Journal of Radioanalytical and Nuclear Chemistry,265, 81(2005), DOI:10.1007/s10967-005-0790-x

16. S.W. Al Rmalli, C.F. Harrington, M. Ayub and P.I. Haris, Journal of Environmental Monitoring, 7, 279(2005), DOI: 10.1039/b500932d

17. S.A. Allen, Chemical analysis of ecological materials, Blackwell, London, (1989),APHA, Standard methods for the examination of waters and wastewaters. APHA- AWWA-WEF, Washington, DC, 1998

18. K.Mohanty, M. Jha, B.C.Meikap and M.N. Biswas,Chemical Engineering Journal,117, 71(2006), DOI: $10.1016 / j . c e j .2005 .11 .018$

19. C. Raji and T.S. Anirudhan, Water Research, 32(12), 3772(1998), DOI:10.1016/S00431354(98)00150-X

20. K. Selvi, S. Pattabhi and K. Kadirvelu, Bioresource Technology, 80, 87(2001), DOI:10.1016/s 09608524(01)00068-2

21. M.D. Converti, M.L. Borgi, G.Ferraiola and Zilline, Chemical and Biochemical Engineering, 16, 195(1992)

22. S. Saraswat and J.P.N Rai, International Journal of Mineral Processing, 94, 203(2010), DOI: 10.1016/j. minpro.2010.02.006

23. E. Lorenc-Grabowska and G. Gryglewicz, Dyes and Pigments,74, 34(2007), DOI:10.1016/j. dyepig.2006.01.027

24. Z. Aksu, U. Acikel, E. Kabasakal and S. Tezer, Water Research, 36, 3063(2002) DOI: 10.1016/s0043-1354(01)00530-9

25. V.K. Gupta, and A. Rastogy, Journal of Hazardous Materials, 163, 39(2009), DOI: 10.1016/j.jhazmat.2008.06.104

26. R. Elangovan, L. Philip and K. Chandraraj, Journal of Hazardous Materials, 152, 100(2008), DOI: 10.1016 / jhazmat.2007.06.067

[RJC-5949/2020] 